\title{
Hygiene of removable partial denture
}

\section{Higiena ruchomych uzupetnień protetycznych}

\author{
Luiza Czerniawska-Kliman ${ }^{\bowtie}$, Katarzyna Grocholewicz
}

Pomorski Uniwersytet Medyczny w Szczecinie, Zakład Stomatologii Zintegrowanej, al. Powstańców Wlkp. 72, 70-111 Szczecin

Pomeranian Medical University in Szczecin, Department of Integrated Dentistry

$\triangle$ luiza_lui@wp.pl

\begin{abstract}
Introduction: Hygiene of removable dental prostheses is equally important as oral hygiene. Statistical data from the World Health Organization show that people over 65 years of age constitute a larger percentage of the population than newly born children. The number of people using removable dental prostheses increases with age. Older people, often for financial reasons, generally opt for settling dentures. Due to its porous structure, acrylic favors the retention of food residue. As a consequence, the incidence of candidiasis and prosthetic stomatopathy increases in patients using removable acrylic dentures.

The aim of the study is to assess the hygiene of the oral cavity and removable dental prostheses.

Materials and methods: A physical examination was carried out to determine the condition of the teeth, oral hygiene, and
\end{abstract}

number/location of missing teeth. Oral hygiene was assessed using the approximal dental plaque index (API). Patients were asked to complete a questionnaire about hygiene and nighttime storage methods for removable dental restorations and whether the doctor provided information on the correct use and storage of prostheses. A physical examination was then performed to determine the hygiene of the restorations. Prosthesis hygiene was evaluated using the hygiene scale of prostheses developed by Frączak et al.

Results and conclusions: The level of oral hygiene in general and hygiene of prosthetic restorations are very low, despite the information obtained from physicians, which indicates that dentists should pay more attention to providing information on oral and prosthesis hygiene, preferably in the form of leaflets. Keywords: dental hygiene; API index; denture hygiene.

\begin{abstract}
ABSTRAKT
Wstęp: Higiena ruchomych uzupełnień protetycznych jest tak samo istotna jak higiena jamy ustnej. Dane statystyczne Światowej Organizacji Zdrowia pokazują, że osoby po 65. r.ż. stanowią większy odsetek populacji niż rodzące się dzieci. Z wiekiem wzrasta liczba osób użytkujących uzupełnienia ruchome. Osoby starsze, często z przyczyn finansowych, decydują się na protezy osiadające. Akryl ze względu na swoją porowatą strukturę sprzyja zaleganiu resztek pokarmowych. W konsekwencji wzrasta częstość występowania kandydozy czy stomatopatii protetycznych u pacjentów użytkujących ruchome protezy akrylowe. Celem pracy była ocena higieny jamy ustnej, ruchomych uzupełnień protetycznych oraz stopnia przekazywania informacji pacjentom przez lekarza oddającego uzupełnienia protetyczne. Materiały i metody: Wykonano badanie przedmiotowe mające na celu określenie stanu zębów, higieny jamy ustnej oraz wszystkich braków zębowych. Higienę jamy ustnej oceniono
\end{abstract}

za pomocą aproksymalnego wskaźnika płytki zębowej (API). Pacjenci zostali poproszeni o wypełnienie ankiety, której pytania dotyczyły sposobu utrzymywania higieny protez i sposobu przechowywania ruchomych uzupełnień protetycznych w nocy oraz tego czy lekarz przekazał informacje odnośnie prawidłowego użytkowania oraz przechowywania uzupełnień. Następnie wykonano badanie przedmiotowe w celu określenia higieny uzupełnień. Higienę protez oceniono za pomocą przeznaczonej do tego celu skali opracowanej przez Frączak i wsp.

Wyniki i wnioski: Poziom higieny jamy ustnej oraz uzupełnień protetycznych jest bardzo niski pomimo informacji przekazanych przez lekarza. Oznacza to, że stomatolodzy powinni zwracać większą uwagę na sposób przekazywania informacji dotyczących higieny jamy ustnej i uzupełnień protetycznych, najlepiej przygotować je w formie ulotki.

Słowa kluczowe: higiena protez; higiena jamy ustnej; wskaźnik API.

\section{INTRODUCTION}

Hygiene of prosthetic dental restorations is just as important as oral hygiene. Statistical data from the World Health Organization show that people over 65 years of age constitute a larger percentage of the population than newly born children [1]. The number of people using removable dental prostheses increases with age. Older people, often for financial reasons, opt for acrylic dentures. Due to its porous structure, acrylic favors the retention of food residue. As a consequence, the incidence of candidiasis and prosthetic stomatopathy increases in patients using removable acrylic dentures. According to Rogers et al. $67 \%$ of prosthetic restorations suffers from stomatopathy [2]. Due to the use of full dentures and often the shortened height 
of the bite, the mouth corners become inflamed. This is the result of saliva accumulating in the folds of the skin causing fungal and staphylococcal infection [3, 4]. The infection of the mucous membrane may be symptomatic or asymptomatic. According to Spiechowicz, bacterial or fungal infections can affect up to $100 \%$ of patients using removable dentures [5]. Candida albicans is the most common causal pathogen in cases of stomatopathy. Oral infections have effects not only locally, but also on the whole organism. Pathogens living in the oral cavity have been implicated in the pathogenesis of several systemic diseases. These are life-threatening diseases, such as bacterial endocarditis, aspiration pneumonia, and general respiratory infection [6].

The aim of the study was to assess oral hygiene, hygiene of removable prosthetic restorations, and the degree of information transfer to patients by the physicians providing the prostheses.

\section{MATERIALS AND METHODS}

Approval for conducting this research was obtained from the Bioethical Commission at the Pomeranian Medical University in Szczecin No. KB-0012/02/13. The test material consisted of 365 patients (200 women and 165 men) between 18-90 years of age, applicants to the Department of Integrated Dentistry of the Pomeranian Medical University in Szczecin and private practices in Szczecin with signed contracts with the National Health Fund. Subjects were asked to complete a questionnaire, in which questions related to the maintenance of prosthesis hygiene, nighttime storage of the removable dental restorations, and whether the doctor provided information on the correct use and storage of prostheses. A physical examination was carried out to determine the condition of the teeth, oral hygiene, and number of missing teeth. Oral hygiene was assessed using the approximal dental plaque index (API) according to Lange et al. [7]. The level of the bacterial plaque was assessed without staining in the interdental spaces. The API was calculated according to the formula:

$$
\text { API }=\frac{\text { Number of interdental spaces with plaque }}{\text { The number of interdental spaces examined }} \times 100 \%
$$

The index results were classified into four categories of hygiene level:

1) API $<25 \%$ optimal oral hygiene;

2) API $=25-39 \%$ fairly good oral hygiene;

3) $\mathrm{API}=40-69 \%$ sufficient (average) hygiene, to improve;

4) API $=70-100 \%$ inadequate oral hygiene.

Next, the hygiene of prosthetic restorations was determined. Prosthesis hygiene was assessed using the prosthesis hygiene scale developed by Frączak et al. [8] presented in Table 1. The results of the study were recorded in the study sheet.

The obtained results were subjected to statistical analysis. The results obtained for the age groups of women and men were compared. The data obtained from the conducted
TABLE 1. The scale of hygiene of prostheses according to Frączak et al. [8]

\begin{tabular}{ll}
\multicolumn{1}{c}{ Degree } & \multicolumn{1}{c}{ Rating } \\
\hline 0 -no prosthesis plaque & no plaque after scraping the tube \\
\hline $\begin{array}{l}\text { 1-plaque visible after } \\
\text { scraping }\end{array}$ & $\begin{array}{l}\text { with a tube we scrape small amounts } \\
\text { of plaque }\end{array}$ \\
\hline $\begin{array}{l}\text { p-small layer of visible } \\
\text { plaque }\end{array}$ & $\begin{array}{l}\text { elements of the prosthesis partially } \\
\text { covered with visible plaque }\end{array}$ \\
\hline 3 -large plaque deposits & $\begin{array}{l}\text { elements of the prosthesis entirely } \\
\text { covered with visible plaque }\end{array}$ \\
\hline
\end{tabular}

tests were of the nominal scale. A $\chi^{2}$ independence test $\left(\chi^{2}\right)$ was used to analyze groups on the nominal scale. The results were assumed to be statistically significant if $p<0.05$. All calculations were performed using the Statistica v 9.0 package.

\section{RESULTS}

The obtained results are presented in the form of tables and figures.

The study determined which teeth were missing in the mouth. The analyses showed statistically significant differences in each of the cases studied. It was found that the number of missing teeth increased with the age of the examined women. In the age group below 30 years of age, the most common missing tooth was the first left molar in the mandible, and the second most common was the first right molar in the mandible. Similar results were observed in other age groups, with the exception of the oldest patients. In the oldest age group, the second left molar was most often missing in the maxilla; a large percentage of missing teeth in this group were left and right molars in the maxilla premolars on the right side of the maxilla, and both first molars in the mandible. Among men, the most commonly missing in subjects less than 30 years of age was the first right mandibular tooth, while in those aged 31-43, it was the first left molar tooth of the mandible. Above 44 years of age, most often both first molars were missing in the mandible.

The percentages of patients with complete loss of teeth in the whole group of subjects are presented in Tables 2 and 3. The data obtained were divided into missing teeth in the maxilla or in the mandible and those completely devoid of teeth on both arches. The obtained results indicate that the highest percentage of edentulousness occurs in the oldest group of subjects.

Oral hygiene was determined using the API, which is expressed as the ratio of interdental spaces with bacterial plaque to all the spaces examined. The results are presented in Table 4. The API values have been assigned different degrees of oral hygiene. The values of the index above $70 \%$ are described as insufficient hygiene, between $70 \%$ and $40 \%$ indicate average hygiene requiring improvement. Good hygiene describes values between $39 \%$ and $25 \%$, and optimal below $25 \%$. Observed values of this index in the examined patients indicated oral hygiene that was insufficient or required improvement. 
TABLE 2. Percentage of toothlessness in particular age groups of women

\begin{tabular}{lccc} 
& \multicolumn{3}{c}{ Edentulism } \\
\cline { 2 - 4 } & maxilla & mandible & overall \\
\hline $18-30$ & $0 \%$ & $0 \%$ & $0 \%$ \\
\hline $31-43$ & $4 \%$ & $0 \%$ & $0 \%$ \\
\hline $44-56$ & $9 \%$ & $4 \%$ & $2 \%$ \\
\hline $57-69$ & $39 \%$ & $17 \%$ & $17 \%$ \\
\hline $70-90$ & $55 \%$ & $31 \%$ & $31 \%$ \\
\hline
\end{tabular}

TABLE 3. Percentage of toothlessness in particular age groups of men

\begin{tabular}{lccc}
\multirow{2}{*}{ Age } & \multicolumn{3}{c}{ Edentulism } \\
\cline { 2 - 4 } & maxilla & mandible & overall \\
\hline $18-30$ & $0 \%$ & $0 \%$ & $0 \%$ \\
\hline $31-43$ & $3 \%$ & $0 \%$ & $0 \%$ \\
\hline $44-56$ & $0 \%$ & $0 \%$ & $0 \%$ \\
\hline $57-69$ & $18 \%$ & $12 \%$ & $12 \%$ \\
\hline $70-90$ & $44 \%$ & $25 \%$ & $25 \%$ \\
\hline
\end{tabular}

TABLE 4. Avarage values of the API in individual age groups

\begin{tabular}{lccccc}
\multirow{2}{*}{ Sex } & \multicolumn{5}{c}{ Age } \\
\cline { 2 - 6 } & $\mathbf{1 8 - 3 0}$ & $\mathbf{3 1 - 4 3}$ & $\mathbf{4 4 - 5 6}$ & $\mathbf{5 7 - 6 9}$ & $\mathbf{7 0 - 9 0}$ \\
\hline Women & $54 \%$ & $55 \%$ & $61 \%$ & $72 \%$ & $72 \%$ \\
\hline Men & $66 \%$ & $64 \%$ & $65 \%$ & $54 \%$ & $67 \%$ \\
\hline
\end{tabular}

TABLE 5. Frequency of visits to dentist in particular age groups of women

\begin{tabular}{lccccc} 
& \multicolumn{5}{c}{ Age } \\
\cline { 2 - 6 } \begin{tabular}{l} 
Frequency of \begin{tabular}{c} 
visits \\
\cline { 2 - 6 }
\end{tabular} \\
\cline { 2 - 6 }
\end{tabular} & $\begin{array}{c}18-30 \\
\text { years }\end{array}$ & $\begin{array}{c}31-43 \\
\text { years }\end{array}$ & $\begin{array}{c}44-56 \\
\text { years }\end{array}$ & $\begin{array}{c}57-69 \\
\text { years }\end{array}$ & $\begin{array}{c}70-90 \\
\text { years }\end{array}$ \\
\cline { 2 - 6 } & $\%$ & $\%$ & $\%$ & $\%$ & $\%$ \\
\hline Every 1/2 year & 10.00 & 14.58 & 13.73 & 11.90 & 0.00 \\
\hline 1 per year & 23.33 & 33.33 & 35.29 & 35.71 & 20.69 \\
\hline Irregularly & 66.67 & 52.08 & 50.98 & 52.38 & 79.31 \\
\hline
\end{tabular}

TABLE 6. Frequency of visits to dentist in particular age groups of men

\begin{tabular}{lccccc} 
& \multicolumn{5}{c}{ Age } \\
\cline { 2 - 6 } \begin{tabular}{l} 
Frequency of \begin{tabular}{c} 
visits \\
\cline { 2 - 6 }
\end{tabular} \\
\cline { 2 - 6 }
\end{tabular} & $\begin{array}{c}18-30 \\
\text { years }\end{array}$ & $\begin{array}{c}31-43 \\
\text { years }\end{array}$ & $\begin{array}{c}44-56 \\
\text { years }\end{array}$ & $\begin{array}{c}57-69 \\
\text { years }\end{array}$ & $\begin{array}{c}70-90 \\
\text { years }\end{array}$ \\
\cline { 2 - 6 } & $\%$ & $\%$ & $\%$ & $\%$ & $\%$ \\
\hline Every 1/2 year & 5.88 & 0.00 & 11.11 & 4.26 & 7.14 \\
\hline 1 per year & 23.53 & 20.59 & 13.89 & 14.89 & 14.29 \\
\hline Irregularly & 70.59 & 79.41 & 75.00 & 80.85 & 78.57 \\
\hline
\end{tabular}

Patients were asked about the frequency of visits to the dental office (Tab. 5 and 6). Three options were included. The results are alarming and show that patients do not report for regular dental check-ups. Most patients, in all age groups, admitted to irregularity of visits to the dentist, which means that the reason for reporting to the doctor is usually the occurrence of a specific problem.
In order to check whether women of different ages significantly differed in frequency of visits, $\chi^{2}$ independence test analysis was performed. Analysis showed no statistically significant differences: $\chi^{2}(8)=10.30 ; p=0.233$. This means that women of different ages did not differ in terms of frequency of visits. Analysis by $\chi^{2}$ test was likewise performed for the different age groups of men. This analysis showed no statistically significant differences: $\chi^{2}(8)=5.86 ; p=0.650$. This means that men of different ages did not differ in terms of frequency of visits.

Another element of our analysis was the question about the way dentures are stored outside the oral cavity during sleep. Some of the patients did not answer the question (6 women and 3 men). Figures 1 and 2 present the results obtained in the study. Analyses showed statistically significant differences in the storage of dentures during the night depending on the age of respondents. Analysis by $\chi^{2}$ independence test for the women provided the following results:

- dry: $\chi^{2}(4)=26.48 ; \mathrm{p}<0.001$,

- in water: $\chi^{2}(4)=5.57 ; p=0.153$,

- in anti-inflammatory solution: $\chi^{2}(4)=26.57$; $p<0.001$,

- no break at night: $\chi^{2}(4)=8.74 ; \mathrm{p}=0.048$.

The $\chi^{2}$ independence test for the men provided the following results:

- dry: $\chi^{2}(4)=14.47 ; p=0.002$,

- in water: $\chi^{2}(4)=8.76 ; p=0.013$,

- in anti-inflammatory solution: $\chi^{2}(4)=10.78 ; \mathrm{p}=0.002$,

- no break at night: $\chi^{2}(4)=20.43 ; \mathrm{p}<0.001$.

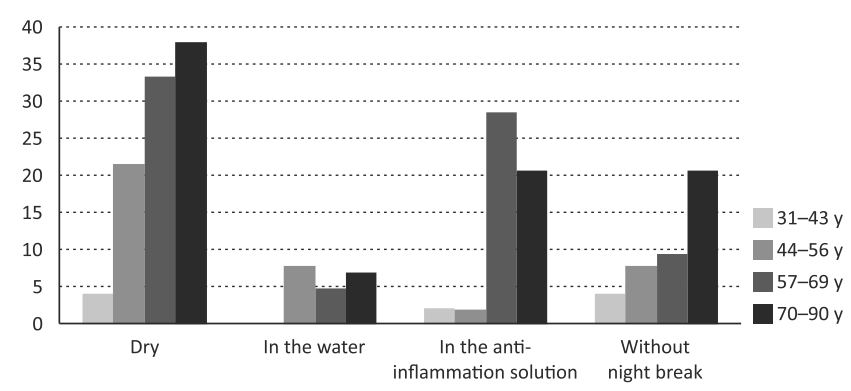

FIGURE 1. Methods of storing prostheses in particular age groups of women

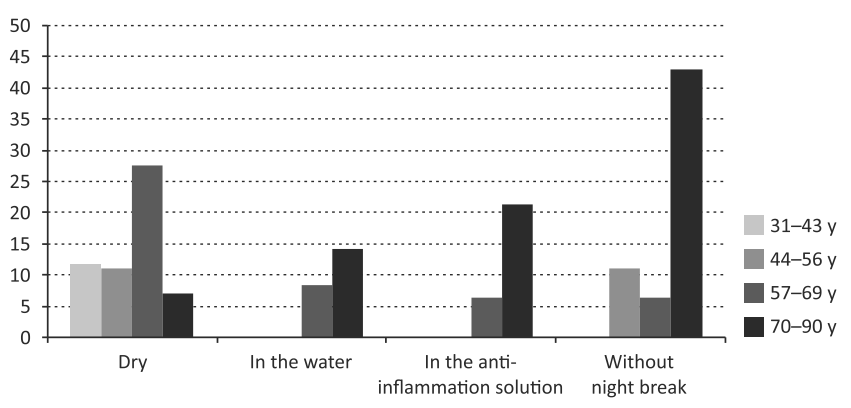

FIGURE 2. Methods of storing prostheses in particular age groups of men

It was found that younger people, aged 31-43, and those 70-90 years of age more often kept dentures "dry" or did not take a break at night. Women over 57 years of age more often than younger women stored prostheses in an anti-inflammatory 
solution. It has been observed that men over 70 years of age more often stored dentures in an anti-inflammatory solution or did not take the night break. Men over 57 years of age more often than younger men stored dentures in water. Men between the ages of 57 and 69 more often kept dentures "dry".

The next question was about cleaning of the prostheses. Patients could choose from 5 answers. The results are presented in Tables 7 and 8. The following data show that patients use different methods for cleansing prostheses. The dominant method among subjects is using a toothbrush in combination with soap, followed by toothbrush with toothpaste, more often chosen by women, while men more often use the toothbrush alone.

It was found that the majority of both men and women of all age groups received information from their doctors regarding the use of prostheses. The results showed that patients are

TABLE 7. Methods of cleaning restorations in individual age groups of women

\begin{tabular}{lcccc} 
& \multicolumn{4}{c}{ Age } \\
\cline { 2 - 5 } Cleaning method & $31-43$ & $\mathbf{4 4 - 5 6}$ & $\mathbf{5 7 - 6 9}$ & $\mathbf{7 0 - 9 0}$ \\
\cline { 2 - 5 } & $\%$ & $\%$ & $\%$ & $\%$ \\
\hline Brush with soap & 6.25 & 11.76 & 35.71 & 37.93 \\
\hline Brush with paste & 0.00 & 9.80 & 21.43 & 27.59 \\
\hline Only a brush & 0.00 & 11.76 & 14.29 & 6.90 \\
\hline Only rinsing & 4.17 & 1.96 & 4.76 & 10.34 \\
\hline I do not wash & 0.00 & 3.92 & 0.00 & 3.45 \\
\hline
\end{tabular}

TABLE 8. Methods of cleaning restorations in particular age groups of men

\begin{tabular}{lcccc} 
& \multicolumn{5}{c}{ Age } \\
\cline { 2 - 5 } Cleaning method & $31-43$ & $44-56$ & $57-69$ & $70-90$ \\
\cline { 2 - 5 } & $\%$ & $\%$ & $\%$ & $\%$ \\
\hline Brush with soap & 5.88 & 11.11 & 19.15 & 14.29 \\
\hline Brush with paste & 0.00 & 0.00 & 10.64 & 21.43 \\
\hline Only a brush & 2.94 & 5.56 & 12.77 & 28.57 \\
\hline Only rinsing & 0.00 & 2.78 & 2.13 & 0.00 \\
\hline I do not wash & 0.00 & 2.78 & 4.26 & 21.43 \\
\hline
\end{tabular}

TABLE 9. Information provided by a physician in individual age groups of women

\begin{tabular}{lcccc} 
& \multicolumn{4}{c}{ Age } \\
\cline { 2 - 5 } $\begin{array}{c}\text { Information from } \\
\text { a physician }\end{array}$ & $31-43$ & $44-56$ & $57-69$ & $70-90$ \\
\cline { 2 - 5 } & $\%$ & $\%$ & $\%$ & $\%$ \\
\hline Yes & 57.14 & 72.73 & 75 & 69.57 \\
\hline No & 42.86 & 27.27 & 25 & 30.43 \\
\hline
\end{tabular}

TABLE 10. Information provided by a physician in individual age groups of men

\begin{tabular}{lcccc} 
& \multicolumn{4}{c}{ Age } \\
\cline { 2 - 5 } $\begin{array}{c}\text { Information from } \\
\text { a physician }\end{array}$ & $\mathbf{3 1 - 4 3}$ & $\mathbf{4 4 - 5 6}$ & $\mathbf{5 7 - 6 9}$ & $\mathbf{7 0 - 9 0}$ \\
\cline { 2 - 5 } & $\%$ & $\%$ & $\%$ & $\%$ \\
\hline Yes & 75.00 & 37.50 & 68.00 & 41.67 \\
\hline No & 25.00 & 62.50 & 32.00 & 58.33 \\
\hline
\end{tabular}

mostly informed by the physician in charge about the proper use of prostheses, although this is not reflected in the level of oral and prosthetic restoration hygiene. The results are presented in Tables 9 and 10.

In order to check whether women of different ages differed in terms of information obtained from the doctor, a $\chi^{2}$ independence test was performed. Analysis by $\chi^{2}$ independence test showed no statistically significant differences: $\chi^{2}(3)=1.16$; $p=0.779$. This means that women of different ages did not differ in terms of information obtained from the doctor.

Similarly for men, analysis by $\chi^{2}$ independence test showed no statistically significant differences: $\chi^{2}(3)=4.06 ; p=0.270$. This means that men of all ages did not differ in terms of information obtained from the doctor.

In the study, the hygiene level of patients' prostheses was evaluated according to the Frączak et al. scale [8]. The results are presented in Tables 11 and 12. The small significant statistical differences indicate that the level of hygiene in men is worse than in women. In the group of younger women, most prostheses showed visible bacterial plaque after removing it with a probe. Among men, hygiene is worse, as demonstrated by the slight build-up of bacterial plaque on the denture plate, visible without mechanical removal. It is alarming that among older age patients, some do not maintain sufficient hygiene of prostheses, which are covered with large deposits of bacterial plaque and calculus.

Analysis by the $\chi^{2}$ independence test showed no statistically significant differences in the group of women: $\chi^{2}(9)=8.66$; $p=0.435$. This means that women of different ages did not differ in terms of the hygiene level of restorations.

Analysis by $\chi^{2}$ independence test showed no statistically significant differences in the group of men: $\chi^{2}(9)=11.06 ; p=0.238$. This means that men of all ages did not differ in terms of the hygiene level of restorations.

TABLE 11. Hygiene level of restorations in individual age groups of women (scale according to Frączak et al. [8])

\begin{tabular}{|c|c|c|c|c|}
\hline \multirow{3}{*}{$\begin{array}{l}\text { Hygiene of } \\
\text { restorations }\end{array}$} & \multicolumn{4}{|c|}{ Age } \\
\hline & $31-43$ & $44-56$ & $57-69$ & $70-90$ \\
\hline & $\%$ & $\%$ & $\%$ & $\%$ \\
\hline 0 & 12.50 & 8.70 & 8.82 & 4.00 \\
\hline 1 & 62.50 & 43.48 & 38.24 & 28.00 \\
\hline 2 & 12.50 & 34.78 & 47.06 & 40.00 \\
\hline 3 & 12.50 & 13.04 & 8.82 & 28.00 \\
\hline
\end{tabular}

TABLE 12. Hygiene level of restorations in particular age groups of men (scale according to Frączak et al. [8])

\begin{tabular}{|c|c|c|c|c|}
\hline \multirow{3}{*}{$\begin{array}{l}\text { Hygiene of } \\
\text { restorations }\end{array}$} & \multicolumn{4}{|c|}{ Age } \\
\hline & $31-43$ & 44-56 & 57-69 & $70-90$ \\
\hline & $\%$ & $\%$ & $\%$ & $\%$ \\
\hline 0 & 0.00 & 0.00 & 3.57 & 0.00 \\
\hline 1 & 25.00 & 33.33 & 32.14 & 16.67 \\
\hline 2 & 75.00 & 44.44 & 39.29 & 16.67 \\
\hline 3 & 0.00 & 22.22 & 25.00 & 66.67 \\
\hline
\end{tabular}


The type of prosthetic restoration was determined in the study. In order to check whether there were differences in the types of prosthetic restorations performed in individual age groups, a $\chi^{2}$ independence test was performed. $\chi^{2}$ analysis in the group of women provided the following results:

- skeletal mandible dentures: $\chi^{2}(4)=13.11 ; p<0.001$,

- skeletal maxilla dentures: $\chi^{2}(4)=8.64 ; p=0.028$,

- acrylic partial prosthesis of the mandible: $\chi^{2}(4)=13.58$; $\mathrm{p}=0.005$,

- acrylic partial prosthesis of the maxilla: $\chi^{2}(4)=21.23$; $\mathrm{p}<0.001$,

- complete mandible acrylic prosthesis: $\chi^{2}(4)=12.75$; $\mathrm{p}=0.006$,

- complete maxilla acrylic prosthesis: $\chi^{2}(4)=55.80$; $\mathrm{p}<0.001$.

Analyzes by $\chi^{2}$ independence test in the group of men provided the following results:

- skeletal mandible dentures: $\chi^{2}(4)=6.62 ; p=0.095$,

- skeletal maxilla dentures: $\chi^{2}(4)=6.20 ; p=0.142$,

- acrylic partial prosthesis of the mandible: $\chi^{2}(4)=19.04$; $\mathrm{p}<0.001$,

- acrylic partial prosthesis of the maxilla: $\chi^{2}(4)=14.24$; $\mathrm{p}=0.002$,

- complete mandible acrylic prosthesis: $\chi^{2}(4)=5.84$; $\mathrm{p}=0.062$,

- complete maxilla acrylic prosthesis: $\chi^{2}(4)=31.25$; $\mathrm{p}<0.001$.

Figures 3 and 4 present the results obtained in the study. The age group of 18-30 years was not included, because none of the respondents possessed prostheses. The analyses showed statistically significant differences in the types of prostheses used at different ages. It was observed that prostheses supplementing missing teeth were most often used by women aged 57-69. This applies to all types of prostheses: skeletal, partial, and complete acrylic. The older women most often had prostheses of the lower jaw. Younger age (31-43 years) patients more often opted for permanent restorations in the jaw. Women over 57 years of age more often had upper complete prostheses. Partial dentures that settled the jaws were usually possessed by women between 44-69 years of age. It was found that men in the 70-90 year age group more often had partial dentures and upper total prosthesis. Men over 44 years of age were more likely than younger men to have partial dentures of the upper jaw. The most common type of prosthesis in the 31-43 year age group was skeletal prosthesis of the jaw, and among patients 44-56 years of age, most common were partial dentures settling in the mandible. In patients aged 57-69, a complete denture of the jaw and partial of the mandible were made with equal frequency. In patients over 69 years of age, partial dentures settling in the mandible and total upper dentures prevailed.

The comparison of results from individual age groups of men and women shows significant differences, especially in the age group 31-43. Among the studied women, partial denture of the lower jaw was the dominant type, while in the same age group of men, the upper jaw denture dominated. Moreover, in

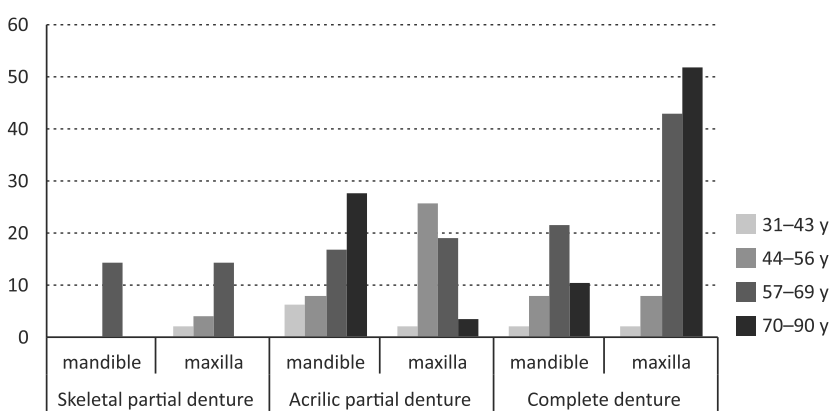

FIGURE 3. Types of prosthetic restorations in individual age groups of women

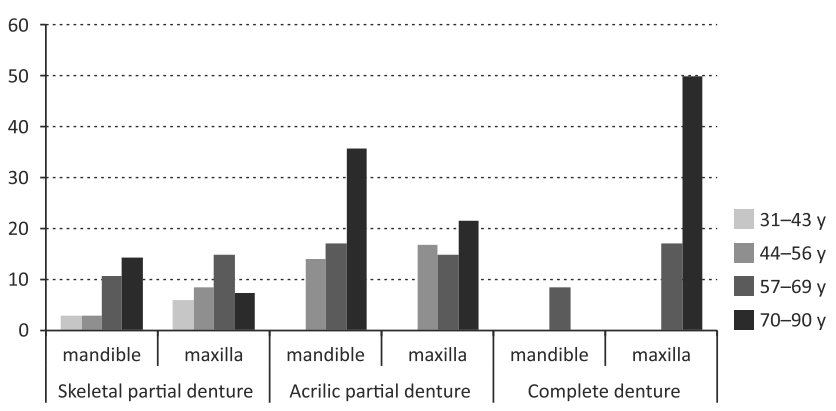

FIGURE 4. Types of prosthetic restorations in individual age groups of men

the group of women, complete dentures were made both in the mandible and in the maxilla, whereas in the same age group of the studied men, there were no partial acrylic dentures or full dentures. In the age group of 70-90 years, the frequency of settling prostheses is similar for the total upper dentures and partial lower ones. The differences in this age group are mainly related to skeletal prostheses, because they were not performed in any of the examined women.

\section{DISCUSSION}

In this study, $50-80 \%$ of respondents admitted to irregular visits to the dental office. Compared to the results of other studies, these results are similar and indicate that the most common reason for reporting to the dental office is the occurence of specific complaints, not the desire to control the general status of the teeth. The results of many studies have shown that more than half of the patients surveyed avoid regular visits to the dentist. As many as $80 \%$ of respondents in Sweden and Denmark and about half of patients in the UK avoid regular visits. Visits once a year are declared by $56.8 \%$ of respondents in Germany and $73.3 \%$ of respondents in Spain $[9,10]$. In health monitoring surveys carried out at the request of the Ministry of Health in Poland, $36 \%$ of respondents declared visits once a year [11]. According to Holm-Pedersen et al. [12], subjective assessment by patients regarding the regularity of their visits to the dental office is always overstated compared to reality. Only $13 \%$ of patients in this study could remember the exact date of their last visit. It follows that patients' assessment of the regularity of visits to the dentist cannot be considered conclusive. Patients tend to declare more visits. In the present 
study, only a small percentage of all participants surveyed report that they visit their dentist regularly, once a year or more often. Most of the respondents do not see any need for regular check-ups, without realizing that early diagnosis will increase the chance of treatment and avoiding complications. The most disturbing results can be seen in a study by Gaszyńska et al. [13]. In answer to the question of why patients do not use dental services, as many as $19.2 \%$ of respondents believe that the dentist is not able to meet the expectations of treatment, and $23.3 \%$ do not see the need for treatment. Similarly, alarming information was provided by the Centre for Public Opinion Research (CBOS), stating that $26 \%$ of the population does not report for follow-up visits, and less than half of respondents regularly visit the dentist once a year [14].

Maintaining adequate hygiene of prostheses is an important element in determining the success of prosthetic rehabilitation. Studies show that hygiene of the oral cavity in the elderly is insufficient. A study by Kaminska-Pikiewicz et al. [15] showed that only one in three people brushes their teeth twice a day, and as many as a sixth of the patients do not brush their teeth or only do it occasionally. Only every twelfth respondent mentions the replacement of the toothbrush every two months. Hygiene of the oral cavity includes not only the hygiene of teeth remaining in the oral cavity, but also the hygiene of prosthetic restorations. Szpak et al. determined the API in a group of subjects between $65^{-74}$ years of age to be $74 \%$, which is indicative of insufficient oral hygiene [16]. These results are similar to those obtained in the present study, in which API was $70 \%$ in respondents over 70 years of age. The oral hygiene index is also high in other age groups, which indicates poor oral hygiene over all ages. Slower results were obtained by Wiatrak et al.; average API scores (API $=40-70 \%$ ) were seen in $72 \%$ of patients in the control group and $53 \%$ of the study group in the first study before hygienization [17]. Researchers have shown that hygiene instruction and motivating patients to improve hygienic behavior result in significant improvement, as demonstrated by an API of $52 \%$ at the level of optimal oral hygiene (API < 25\%).

Extensive plaque coverage of complete or partial acrylic dentures promotes the growth of bacteria. In addition, acrylic as a porous material - facilitates the colonization of bacteria $[18,19,20,21]$. This is a frequently overlooked problem. Sesma et al. [22] proved the relationship between the thickness of the bacterial plaque on the prosthesis before and after coating the mucosal part of the prosthesis with varnish. The authors found that the surface of the prosthesis plate that was covered with a layer reducing the porosity of the acrylic was covered to a much lesser extent with bacterial plaque. The disadvantage of this method is the fact that after 3 months, cracks in the surface of the varnish were revealed under electron microscope, which, like the structure of the acrylic, were sites of bacterial colonization. The mucous membrane under the denture plate on which food debris accumulates is often overlooked during the cleaning process [23]. Most patients are not aware of this fact, because doctors often do not inform about the need to clean the mucosa gently, especially under the extensive denture plate. Research by Bartczyszyn et al. show that the hygiene level of prostheses is not satisfactory, because up to $94 \%$ of restorations are improperly cleaned. In our study, this percentage is much lower and amounts to $47 \%$ of the subjects, in whom large deposits of plaque on the prosthesis plate were found. The blame lies with both patients and doctors [24]. In Poland and beyond, poor hygiene results are found. In a study by King and Kapadia, $37 \%$ of respondents do not maintain sufficient oral hygiene, and $7 \%$ do not visit the dentist [25]. However, in the studies of Kruszyńska-Rosada et al., $85 \%$ of patients aged between $35-44$ years maintained their removable restorations in good hygienic condition [26]. This is a slightly higher result than found in this study for the age group of 31-43-year-old women (75\%), while in the same age group of men the results were much worse (25\%). It seems, however, that younger people generally take better care of the hygiene of not only the oral cavity, but also prosthetic restorations. In older people, hygiene is at a much worse level. This may be due to the fact that manual skills deteriorate with age and motor system mobility changes. This may result in poor cleaning of restorations or its complete abandonment. As many as $11.6 \%$ of patients do not wash the prosthesis and $44 \%$ store the prostheses in water [27].

It may appear that the method for cleansing prostheses is quite obvious, but research shows a completely different reality. In research from Wroclaw, $56 \%$ of patients use toothpaste while brushing their dentures [24]. Different results were obtained by researchers from Brazil, where the majority of respondents - $84.9 \%$ - use toothbrushes, water, and chemical denture cleansers [23]. In Turkey, the majority of examined people also use toothbrushes and toothpastes to clean their dentures, but as much as $10 \%$ do not clean their dentures at all [28]. The Polish studies of Smolana et al. show that the majority of respondents $-55 \%$ - clean the prosthesis at least once a day and most often, $82 \%$ - using a brush and toothpaste [29]. In our study, different results were obtained. The examined patients most often used a toothbrush in combination with soap. This may indicate different preferences of patients and different measures recommended by doctors for maintaining proper hygiene of restorations. Daily hygienic maintenance of dentures, according to many authors, should consist of cleaning the dentures with a soft brush using a washing agent and thoroughly rinsing before putting them back into the oral cavity. Cleaning agents without abrasive additives should be used to remove the bacterial plaque from the prosthesis plate, especially its mucosal parts, as they may cause damage and scratches in the acrylic [6]. In this study, the most commonly used denture hygiene product was ordinary soap combined with mechanical cleaning using a brush. In the second place, women used toothpaste with a toothbrush and men used toothbrush alone. Some of the respondents $(16.7 \%)$ declared that no means of cleaning were used. The high prevalence of insufficient denture hygiene may indicate a failing in the way doctors provide information. Doctors providing prosthetic work may not always provide information on proper hygiene. Bartczyszyn et al., in their 
studies, showed that $65 \%$ of patients using prosthetic restorations did not receive information from their doctors on how to maintain dentures in good condition [24]. In studies by Peracini et al., $51.89 \%$ of patients did not know how to properly clean dentures, because they were not given appropriate guidelines [23]. Conversely, a study conducted among doctors showed that almost $94 \%$ of dentists inform their patients about the proper hygiene of dentures. The most frequently recommended method (78\%) of proper hygiene is brushing the prosthesis and immersing in a solution of denture hygiene tablets [30]. Comparing the above data with the results of our own research, where despite a large percentage of patients being informed by physicians about the hygiene of prostheses it is not maintained at a good level, it seems that doctors should pay more attention to providing information on maintaining good hygiene. The problem lies in the way information is conveyed. Most patients, because of the stress that accompanies the visit to the dentist's office, forget what the doctor has given them. This may also results from the fact that oral information is not remembered by patients, especially those of older age. A better solution is to provide written information, allowing patients to be reminded of hygiene knowledge by re-reading it.

The use of removable dentures is associated with the disadvantage that they have to be removed from the oral cavity, especially at night. In Smolana et al. studies, as many as $45 \%$ of patients do not remove dentures at night [29]. Likewise, in the studies of Frączak et al., almost $40 \%$ of respondents do not take off their prostheses overnight $[8,27]$. In the present study, $32 \%$ of patients do not observe the night break in the group of women and men over 70 years of age, which is slightly lower than in the above-mentioned studies. Much better results were obtained by Dolan et al., where only $14 \%$ of patients did not allow the mouth to rest at night [31]. Researchers have observed a relationship between the time of use of the restorations and the frequency of pathologies of the mucous membrane. The longer the patients use the prostheses without keeping the night-time break, the higher the frequency of Candida infections [6]. However, in the studies of Yilmaz et al., there was no statistically significant correlation between the occurrence of stomatopathy and the use of prostheses without night interruption, whereas there was a relationship between the hygiene of the prosthesis and inflammation of the mucosa under the prosthesis plate [32]. Similarly, no relation between the hygiene of prostheses and the quality of life of patients using removable restorations has been proven [33].

\section{CONCLUSIONS}

1. Patient awareness of the correct care of prosthetic restorations is low.

2. Both the level of oral hygiene and hygiene of prosthetic restorations is very unsatisfactory. People with poor oral hygiene also demonstrated insufficient care for prosthetic restorations.
3. A majority of dentists do not provide patients with adequate information regarding the care of prosthetic restorations.

4. The physician providing the patient with a prosthesis should provide detailed instructions on oral hygiene and restorations, preferably in the form of a leaflet.

\section{REFERENCES}

1. Razak PA, Richard KMJ, Thankachan RP, Hafiz KAA, Kumar KN, Sameer KM. Geriatric oral health: a review article. J Int Oral Health 2014;6(6):110-6.

2. Rogers H, Wei X-Q, Lewis MAO, Patel V, Rees JS, Walker RV, et al. Immune response and candidal colonization in denture associated stomatitis. J Clin Cell Immunol 2013;4(6):178. doi: 10.4172/2155-9899.1000178.

3. Kusa-Podkańska M, Skiba M, Wysokińska-Miszczuk J. Starzenie się społeczeństwa i działania w kierunku wydłużenia okresu sprawności jamy ustnej. Zdr Publ 2005;115(3):434-6.

4. Nawrocka-Furmanek J. Wpływ użytkowania protez częściowych na ruchomość zębów. Ptotet Stomatol 2005;55(4):241-8.

5. Spiechowicz E. Dylematy współczesnej rehabilitacji protetycznej. Protet Stomatol 2006;56(3):175-85.

6. Mierzwińska-Nastalska E. Zasady użytkowania, czyszczenia i pielęgnacji protez całkowitych. Protet Stomatol 2011;59(4):293-303.

7. Lange DE, Plagmann H-C, Eenboom A, Promesberger A. Klinische Bewertungsverfahren zur Objektivierung der Mundhygiene. Dtsch Zahnarztl Z 1977;32:44-9.

8. Frączak B, Aleksandruk G, Brzoza W, Chruściel-Nogalska M. Higiena jamy ustnej oraz ruchomych uzupełnień protetycznych. Czas Stomatol 2009;62(3):202-9.

9. Montero J, Albajedo A, Zalba JI. Influence of the usual motivation for dental attendance on dental status and oral health - related qqality of life. Med Oral Patol Oral Cir Bucal 2014;19(3):e225-31.

10. Cornejo M, Pérez G, de Lima KC, Casals-Peidro E, Borrell C. Oral HealthRelated Quality of Life in institutionalized elderly in Barcelona (Spain). Med Oral Patol Oral Cir Bucal 2013;18(2):e285-92.

11. Stan zdrowia jamy ustnej i jego uwarunkowania w populacji polskiej w wieku 35-44 i 65-74 lat. Ministerstwo Zdrowia. http://www.mz.gov. pl/zdrowie-i-profilaktyka/programy-zdrowotne/wykaz-programow/ monitorowanie-stanu-zdrowia-jamy-ustnej-populacji-polskiej-wlatach-2013-2015 (18.04.2015)

12. Holm-Pedersen P, Vigild M, Nitschke I, Berkey DB. Dental care for aging populations in Denmark, Sweden, Norway, United Kingdom, and Germany. J Dent Educat 2005;69(9):987-97.

13. Gaszyńska E, Szatko F, Godala M, Gaszyński T. Oral health status, dental treatment needs, and barriers to dental care of elderly care home residents in Lodz, Poland. Clin Interv Aging 2014;9:1637-44.

14. Pawlik AA. Aktualny stan zdrowia jamy ustnej Polaków - próchnica i choroby przyzębia. Twój Prz Stomatol 2010;11;84-6.

15. Kamińska-Pikiewicz K, Bachanek T, Madejczyk M, Samborski D, Sochaczewska-Dolecka A. The influence of social and living environment on development of oral hygiene habits In people over the age of 65. Pol J Oral Health 2014;124(2):66-9.

16. Szpak A, Stokowska W, Gołębiewska E. Stan uzębienia i potrzeby lecznicze mężczyzn w wieku 64-74 lata zamieszkałych w Białymstoku. Probl Hig Epidemiol 2012;93(1):97-104.

17. Wiatrak K, Morawiec T, Rój R, Mertas A, Machorowska-Pieniążek A, Kownacki $\mathrm{P}$, et al. Oral health of patients treated with acrylic partial dentures using a toothpaste containing bee product. Evidence-Based Complementary Alternative Medicine 2017;(4):1-12. doi: 10.1155/2017/4034179.

18. Czerniawska-Kliman L, Nowak A. Higiena ruchomych uzupelnien protetycznych. Twój Prz Stomatol 2013;1-2:40-2.

19. Kurnatowska AJ, Bieniek J. Poziom bakterii próchnicotwórczych u użytkowników częściowych osiadających uzupełnień protetycznych akrylowych. Protet Stomatol 2006;56(2):130-5.

20. Mierzwińska-Nastalska E. Zasady użytkowania, czyszczenia i pielęgnacji protez całkowitych. Protet Stomatol 2011;59(4):293-303.

21. Nawrocka-Furmanek J. Wpływ użytkowania protez częściowych na ruchomość zębów. Ptotet Stomatol 2005;55(4):241-8. 
22. Sesma N, Lagana DC, Morimoto S, Gil C. Effect of denture surface glazing on denture plaque formation. Braz Dent J 2005;16(2):129-34.

23. Peracini A, Adnrade IM, Paranhos HFO, Silva CH, Souza RF. Behaviors and hygiene habits of complete denture wearers. Braz Dent J 2010;21(3):247-52.

24. Bartczyszyn M, Jaczewski M, Tomalik I. Evaluation of removable dentures hygiene level and oral cavity mucous condition among longterm care houses inhabitants in Wrocław. Dent Med Probl 2005;42(3): 477-81.

25. King T, Kapadia D. Oral health status and treatment needs of institutionalized eldery and disadvantaged population in Fiji (1997). Pac Health Dialog 2003;10(1):35-40

26. Kruszyńska-Rosada M, Hędzelek W, Borysewicz-Lewicka M. Protetyczne potrzeby lecznicze mieszkańców Wielkopolski - badania epidemiologiczne osób w wieku 35-44 lat. Protet Stomatol 2004;54(2):128-32.

27. Frączak B, Stawska B. Potrzeby protetyczne pensjonariuszy Domów Opieki Społecznej. Protet Stomatol 2006;56(4):305-11.
28. Ozkan Y, Özcan M, Kulak Y, Kazazoglu E, Arikan A. General health, dental status and perceived dental treatment needs of an eldery population in Istanbul. Gerodontology 2011;28:28-36.

29. Smolana A, Szypowska A, Wieczorek A, Ryniewicz W, Loster JE. Hygiene habits and conditio of oral mucosa in patients using acrylic removable dentures. J Stoma 2017;70(3):250-60.

30. Dikbas I, Kokosal T, Bal B, Ozkurt Z, Kazaoglu E. A survey of dentists' attitudes toword denture cleansing. OHDMBSC 2006;5(4):7-11.

31. Dolan TA, Gilbert GH, Duncan RP, Foerster U. Risk indicators of edentulism, partial tooth loss and prosthetic status among black and white middleaged and older adults. Community Dent Oral Epidemiol 2001;29:329-40.

32. Yilmaz HH, Aydin Ü, İpek C. Is denture stomatitis related with denture hygiene? Kusadaki 2002;44(4):412-4.

33. Souza RF, Terada ASS, DellaVecchia MP, Regis RR, Zanini AP, Paranhos HFO, et al. Association between denture hygiene and oral health - related quality of live in edentoulus patients. Rev Odontol UNESP 2012;41(1):48-53. 